\title{
Banking on bullshit: Indifferences toward truth in corporate social responsibility
}

\begin{abstract}
Purpose: This article attempts to identify and deconstruct bullshit in banks' corporate social responsibility (CSR) communication in order to advance the management rhetoric research space, which has been characterised by an indifference to truth and meaning.
\end{abstract}

Design/methodology/approach: We provide a typology of bullshit phenomena overview in the banking sector and follow McCarthy et al. 's (2020) C.R.A.P. framework to showcase how bullshit can be comprehended, recognised, acted against and prevented.

Findings: This paper puts a spotlight on written and spoken language to detect bullshit in banks' CSR statements. It provides actionable insights into how stakeholders can act against and prevent bullshit statements from occurring in the future.

Research limitations/implications: Future research is warranted to assess the use of still imagery, events and video materials in corporate communications and non-financial reporting. Further rigorous assessment of actual CSR initiatives must be undertaking to assess claimed contributions.

Practical implications: Monitoring mechanisms and independent assurance statements prepared by authorised third parties may strengthen the motivation and ethicality of CSR activities.

Originality/value: This viewpoint is the first to follow the C.R.A.P framework and critically assess indifferences toward truth in banks' CSR communications.

\section{Introduction}

Corporate social responsibility (CSR) has become an essential part in larger banks to highlight and promote their socially responsible behaviour with the objective of maintaining and building trust with their customers and wider stakeholders (e.g. Branco and Rodrigues, 2006; Fatma and Rahman, 2016; Khan et al., 2016; McDonald and Rundle-Thiele, 2008; Pérez and Del Bosque, 2012). The financial service industry has earned itself much media and public scrutiny - in fact, in a 2013 European-wide consumer survey it was ranked at the bottom compared to other industries approach to demonstrating responsibility towards society (European Commisson, 2013). More recently, industry research states that only 20 per cent of Australian customers believe that 'banks in general are ethical - they do what is good, right and fair' (Deloitte, 2018). Financial services rank as last sector globally by some distance in the Edelman Trust Barometer (2020) - and has done so consistently over the last eight years, albeit since having closed the gap to the second-last of the other 15 sectors measured.

In particular, in the aftermath of the banking-related scandals (e.g. Gandy, 2019; MacDonald, 2017; Toms, 2019), scholars found that companies often used CSR to deflect and distract from - partially self-inflicted - scandals with responses ranging from 'amoral justifications' (Norberg, 2018) and the 'illusion of transparency' (Coombs and Holladay, 2013) to 
constructing a 'false consciousness' among consumers (Prasad and Holzinger, 2013). In other words, banks decided that instead of 'taking responsibility, talking about responsibility is the way of responding to mounting criticism against the finance industry' (Norberg, 2018, p. 403). Therefore, it may not come as surprise that McDonald (2014) integrative review of international empirical research on CSR in the banking industry found that the dominant CSR theme in CSR banking research was CSR communication and reporting practices.

In this article, we argue that forms of social responsibility in the banking sector and the associated internal and external communication consist of bullshit (Christensen et al., 2019; Cohen, 2012; Frankfurt, 2009; Rasche, 2018). Bullshit in CSR can be described as meaningless language with the goal to deceive others about a company or its related performance (Rasche, 2018; Spicer, 2017). It is important to emphasise that bullshitting is different from lying, thereby also different to greenwashing and whitewashing. A liar is aware of the truth, but seeks to avoid it, while the bullshitter does care less about the truth. As Frankfurt (2009) states 'It is just this lack of connection to a concern with truth - this indifference to how things really are - that I regard as the essence of bullshit' (p. 33).

A fitting example of bullshitting versus lying are the responses from the bank CEOs from the Halifax Bank of Scotland (HBOS) and Royal Bank of Scotland (RBS) who oversaw the collapse of their banks during the global financial crisis (GFC). The CEOs tried to distance themselves from any responsibility by arguing they did not have that much influence in their institutions, with Andy Hornby, former CEO of HBOS stating: 'I am very sorry about what has happened at HBOS; it has affected shareholders... it has clearly affected taxpayers; and we are extremely sorry for the turn of events that has brought it about' (Treasury Committee, 2008, p. 48). These responses are not lies - in fact, the CEOs blamed the systems complexity, neglected crucial details and used suggestive words instead of a detailed response that suggested how this could have been prevented. In other words, 'their favoured response was bullshit' (Spicer, 2017, p. 63).

However, although bullshit seems to be a common part in workplaces, only limited attention has been given to better understand or to deal with corporate bullshit, in particular in a banking context. In an attempt to close that gap, this article identifies and deconstructs bullshit in CSR in the context of the banking sector in order to advance the management rhetoric research space. Within this endeavor, we provide a typology of bullshit phenomena and examples. This leads us to present ways how bank managers, corporate communicators and regulators can intervene to stop the creation and proliferation of CSR bullshit. This is achieved by following the C.R.A.P. framework based on McCarthy et al. (2020) that details how to comprehend, recognise, act against and prevent CSR bullshit.

\section{CSR in banking equals banking on bullshit?}

Banks play an important economic social role as they 'perform a service for society and [are] essential to everyday life' (Chambers and Day, 2009, p. 5). Banks enable people and businesses to participate in an economic society based on financial transactions, and it is considered difficult for people and businesses to participate in today's economic society without them. Hence, researching CSR bullshit is particularly relevant in the financial context, as critical observation suggests it to be a structural feature of bank management rhetoric, and as the sector has several characteristics that differentiate bank behaviour from other industries. 
Firstly, in contrast to other industries, many larger banks have in fact gotten even bigger and would today even more so be considered as 'too big to fail', thereby potentially leading to a 'moral hazard' as bank managers are willing to leverage their risks onto the public (Ioannou et al., 2019). Secondly, the incentive structures deliberately favour short-termism, which encourage investments in high-risk high-return assets, thereby establishing and supporting a system with very limited precautions (Hellmann et al., 2000). Many executives still paid themselves outrageous bonuses even during and following the government trillion-dollar bailout following the GFC (Collins, 2015). Thirdly, bankers often have a undeveloped moral understanding (see Luyendijk, 2016), have been subtly brainwashed from a young age to finding themselves 'slick' and 'world-class', but in fact are operating 'below mature practice' (see Australian Prudential Regulation Authority, 2018; Hooton, 2018), leading to potential lack of knowledge that encourages bullshitting to 'fit in' (Cohen, 2012). Fourth, many banks face major conflicts of interests that are in direct competition to CSR aims. For example, banks 'share responsibility because they lend to firms that pollute, produce unsafe products, violate human rights, and are agents of corruption, among other things equally detrimental to the society' (Castelo, 2013, p. 141).

Increasingly, society is taking an interest in banks' corporate action and reacts with skepticism since banking institutions have been involved in frequent financial scandals with 'questionable practices' (Johnson and Kwak, 2010, p. 197) and 'bogus sources of growth' (MacDonald and Robinson, 2010, p. 256). For example, the excessive risk-taking and increased borrowing that took place prior to the GFC many started to question this essential role of banks that had become too big to fail. As a response to the mounting skepticism in society, an increasing number of banks engaged in CSR practices in an attempt to improve public perceptions (Bennett and Kottasz, 2012; Mogaji et al., 2020; Norberg, 2018; Weber et al., 2014; Wiek and Weber, 2014; Xu et al., 2020).

Clearly, CSR has quickly become an 'en-vogue' management idea and a business case for CSR has been constructed since the start of the millennium (Arli, 2010; Breitbarth, 2011; Munro et al., 2018), with rhetoric used as a critical resource to charge its wide uptake (Arli and Tjiptono, 2014; Breitbarth et al., 2018). Consequently, CSR comprises a crucial element in corporate marketing strategies (Fatma et al., 2015; Munro et al., 2016; Rundle-Thiele et al., 2012) due to its capability to positively influence a company's brand image (Brønn and Vrioni, 2001; Chomvilailuk and Butcher, 2013; McDonald and Lai, 2011; McDonald and Rundle-Thiele, 2008; Poolthong and Mandhachitara, 2009). Yet, experimental research has even shown that the more a company advertised their corporate benevolence the more likely their staff were to misbehave (List and Momeni, 2017).

Nevertheless, through CSR initiatives companies are able to present themselves as social 'agents of change' with a goal to better society through a commitment to sustainable development. Consequently, companies create internal and external practices to reflect these commitments by, for example, developing codes of conduct, the issuing of CSR reports or collaborations with local or international initiatives (such as the Global Reporting Initiative (GRI) or the World Business Council of Sustainable Development (WBCSD)). In its basic form, companies engage in CSR activities to maintain the business' legitimacy and gain 'a license to operate' (Condosta, 2012; Lock and Seele, 2015). In that regard, it may be a timely response, as a growing sophistication in stakeholder expectations about CSR communication can be observed: the 2012 Cone Communication study found that 84 per cent of surveyed US citizens wanted a company not just to communicate about its CSR activities, but to clearly 
demonstrate the program outcomes (McDonald, 2014) particularly in a banking industry context due to its unique economic and social role in society.

However, CSR claims are increasingly exposed to social skepticism, which leads consumers to question the authenticity of some CSR programs (Arli and Lasmono, 2010; Kim and Lee, 2009; Skarmeas and Leonidou, 2013). A mounting number of critics of large corporations doubt the CSR claims are honest, but that many managers use CSR rather as a tool to 'reify the hegemonic authority of large corporations' (Prasad and Holzinger, 2013, p. 1915) and that CSR is intended primarily to promote corporations - and not to advance the social good in any meaningful way (Debeljak et al., 2011; Pope and Wæraas, 2016; Skarmeas and Leonidou, 2013).

This behaviour is what Shim and Yang (2016) call 'corporate hypocrisy', which refers to the ethical judgement of company's social engagement and initiatives, in relation to the belief that the company claims to be something that it is not. In a CSR context, that means instead of focusing on 'substantive CSR', i.e. genuine actions, a company focuses on 'symbolic CSR', i.e. greenwashing (Donia and Sirsly, 2016; Herold and Lee, 2017). In other words, companies only appear to be socially responsible from an external view, but internally, these companies "maintain irresponsible standards, systems and processes" (Arli et al., 2019, p. 707).

\section{Bank CSR bullshit: a typology}

As part of CSR, internal and external stakeholders are progressively confronted and undermined by bullshit (Frankfurt, 2009; Rasche, 2018). According to Cohen (2012) bullshit is characterised by an 'unclarifiable unclarity' (p. 105) that is, by using statements that are vague, airy, and obscure or when the key terms can be replaced without altering its plausibility. A good example of bullshit in the banking sector was revealed by high-level governmental and regulatory inquiries such as the 2017-2019 Australian Royal Commission into Misconduct in the Banking, Superannuation and Financial Services Industry, leaving the commissioner publicly wondering whether there is 'a disconnect between what the banks are saying in their advertising, their annual reports, their other public documents, and their conduct?' (Alberici, 2018 n.p.n.).

Scholars argue that bullshit is more prevalent and common than ever before (e.g. Berthon and Pitt, 2018; Cooke, 2017; Flaxman et al., 2016; Mihailidis and Viotty, 2017) given today's post-truth attitude (Ball, 2017; Keyes, 2004) which has also entered the corporate world, is dominated by the so-called truthiness (which links validity to feelings instead of facts) postfact communication (simply ignoring facts) or echo-chambers (where bullshit is amplified through positive-feedback loops). In other words, business bullshit 'seems to be everywhere, and refers to anything, and nothing' (Spicer, 2017, p. 62).

Bullshit often occurs when one has to give an opinion on issues on which they have little or no knowledge about. Petrocelli (2018) further argues that bullshit can only happen if these comments are addressed to an audience that does not have a full picture of the issue and when there is little or no accountability for generating bullshit. In a corporate context, managers seem particularly susceptible to bullshit as their status allegedly self-permits them to announce uninformed and unchallenged opinions on everything, thus often addressing matters 
that exceed their knowledge about that matter (Frankfurt, 2009). Bullshit also seems to be more likely to occur during organisational crises, as uncertain eventualities and rumors increase the likelihood of bullshitting (Christensen et al., 2019; McCarthy et al., 2020).

But not all CSR bullshit can be considered harmful, as audiences are aware that some statements should not be taken too seriously (Spicer, 2017). Instead, Rasche (2018) argues that some ambitious CSR statements include a 'necessary emptiness' which may motivate staff to either induce change by revisiting existing practices or to hold a company more accountable. Likewise, the link - and, arguably, interdependence - between 'rhetoric' and 'reality' has attracted a stream of literature (e.g. Barth and Wolff, 2009; Lee et al., 2016; Moon, 2002; Slack, 2012) including arguments that more general and vague management ideas such as CSR allow for local implementation due to their translucency, transferability and context-specific adaptability (Breitbarth et al., 2011). If this is the case, CSR bullshit may trigger 'self-fulfilling prophecies' (Christensen et al., 2019).

However, in the corporate world, in particular in banking, it must be distinguished between this type of rather harmless or even helpful bullshit, and bullshit that may damage the corporation and present a problem for future sustainable business practices. We provide a typology of bullshit in corporations in a banking context in Table 1. For the purpose of our research, we follow the typology approach of Seele and Lock (2015), who categorized CSR communication along instrumental and deliberative tools as well as published (external) and unpublished (internal) CSR communication. The construction and use of typologies cannot only help to clarify the different aspects that lead to certain phenomena, but also to highlight and structure the complexity of relationships between actors and problems (Brennan, 1987; Compas et al., 1995).

Table 1. Typology of bullshit phenomena with banking examples (adapted from McCarthy et al. (2020)

\begin{tabular}{|l|l|l|}
\hline $\begin{array}{l}\text { Bullshit } \\
\text { phenomena }\end{array}$ & Description of bullshit phenomena & Banking examples \\
\hline $\begin{array}{l}\text { Bullshit } \\
\text { company }\end{array}$ & $\begin{array}{l}\text { Slogans which do not truly reflect } \\
\text { the corporations value proposition } \\
\text { (e.g. promised benefits to clients) } \\
\text { and values (e.g. practices/culture) } \\
\text { (Lee et al., 2019) }\end{array}$ & $\begin{array}{l}\text { Slogans such as 'More Give, Less Take' and 'More } \\
\text { than Money' used by the National Bank Australia } \\
\text { (NAB) to advertise their services, which contradict } \\
\text { the findings of the royal commission's report in 2018, } \\
\text { who identified that five of the nation's largest banks, } \\
\text { including NAB, have improperly collected fees for } \\
\text { services that were never provided (Battersby, 2016; } \\
\text { Lanin, 2018). }\end{array}$ \\
\hline $\begin{array}{l}\text { Bullshit } \\
\text { statements }\end{array}$ & $\begin{array}{l}\text { Statements in any form (e.g. } \\
\text { written, spoken, graphics) without, } \\
\text { willingly or unwillingly, telling the } \\
\text { complete truth, leaving out crucial } \\
\text { details or without any regard for } \\
\text { the truth (Ball, 2017; Hopkin and } \\
\text { Rosamond, 2018) }\end{array}$ & $\begin{array}{l}\text { Statements such as 'Our entire culture is centered on } \\
\text { doing what is right for our customers' (from the CEO } \\
\text { of Wells Fargo) or 'I'm not aware of any overbearing } \\
\text { sales culture' (from the CFO of Wells Cargo) in } \\
\text { response to the incentive-compensation program that } \\
\text { made it possible for its employees to pursue } \\
\text { underhanded sales practices, where Wells Fargo } \\
\text { misled shareholders by creating 3.5 million fake- } \\
\text { accounts and charging customer fees they did not } \\
\text { know about (CNBC, 2018; McGrath, 2016). }\end{array}$ \\
\hline $\begin{array}{l}\text { Marketing } \\
\text { bullshit }\end{array}$ & $\begin{array}{l}\text { Exaggerated or false claims by } \\
\text { marketers that amplify the features } \\
\text { and performance of a product or } \\
\text { service (Dobscha, 1998; Scrizzi, }\end{array}$ & $\begin{array}{l}\text { Subprime products that led to the GFC, where } \\
\text { customers were not made aware of the risks of } \\
\text { subprime loans - bank behaviour in subprime lending } \\
\text { markets comprised that borrowers misjudge their true }\end{array}$ \\
\hline
\end{tabular}




\begin{tabular}{|c|c|c|}
\hline & 2007) & $\begin{array}{l}\text { probability of default and lose their homes in } \\
\text { foreclosure, while lenders know the true odds, but } \\
\text { would recover enough in foreclosure that they lend } \\
\text { anyhow (Fisher, 2009). }\end{array}$ \\
\hline Jargon bullshit & $\begin{array}{l}\text { Words or expressions used by a } \\
\text { particular group to make } \\
\text { something seem legitimate and } \\
\text { enticing, while also muddling } \\
\text { language and thinking (Spicer, } \\
\text { 2017) }\end{array}$ & $\begin{array}{l}\text { Jargon such 'quantitative easing', which was used } \\
\text { during the GFC to inject cash into the economy to } \\
\text { stimulate lending and economic growth. While the } \\
\text { term quantitative easing is it not deliberately } \\
\text { misleading, it doesn't sound like anything big, } \\
\text { experimental, scary and strange - which is what } \\
\text { many economists think it is' (Lanchester, 2014). }\end{array}$ \\
\hline Hearing bullshit & $\begin{array}{l}\text { Statements by managers/ } \\
\text { executives that are not triangulated } \\
\text { with regard to the truth, without } \\
\text { concern for the veracity of the } \\
\text { statement in question, deflect } \\
\text { responsibility or blame the } \\
\text { situation (Hopkin and Rosamond, } \\
\text { 2018; Jizi } \text { et al., 2014; Whittle and } \\
\text { Mueller, 2012) }\end{array}$ & $\begin{array}{l}\text { Hearing statements such as 'You've got to come back } \\
\text { to why do we exist and what is our vision' and NAB } \\
\text { wanted to inspire its people 'from their head and their } \\
\text { heart to living the purpose and vision' (from the CEO } \\
\text { of NAB) in response to what would stop banks from } \\
\text { chasing short-term profits, rather than looking after } \\
\text { their customers in future. The royal commission } \\
\text { revealed multiple transgressions of banks in } \\
\text { Australia, NAB being one of them (Maley, 2018). }\end{array}$ \\
\hline $\begin{array}{l}\text { Internal } \\
\text { communication } \\
\text { bullshit }\end{array}$ & $\begin{array}{l}\text { Internal messages without no or } \\
\text { little regard for the truth but to } \\
\text { convince employees of the } \\
\text { correctness of a particular course } \\
\text { of action (Hudson, 2014) }\end{array}$ & $\begin{array}{l}\text { Internal emails stating that Lehman Brothers' top } \\
\text { people forgo multimillion-dollar bonuses to 'send a } \\
\text { strong message to both employees and investors that } \\
\text { management is not shirking accountability for recent } \\
\text { performance' just before the collapse, thus wanting to } \\
\text { convince investment bankers to further invest in } \\
\text { Lehman Brothers (Fitzgerald, 2009). }\end{array}$ \\
\hline $\begin{array}{ll}\text { Bullshit } & \text { CSR } \\
\text { initiatives } & \end{array}$ & $\begin{array}{l}\text { Initiatives, collaborations or } \\
\text { engagements with local or global } \\
\text { organisations that pretend to help } \\
\text { social or environmental causes, but } \\
\text { are rather tick-box exercises or } \\
\text { implemented for risk management } \\
\text { purposes (Debeljak et al., 2011; } \\
\text { Rim and Kim, 2016) }\end{array}$ & $\begin{array}{l}\text { Participating in international programs and standards } \\
\text { such as Global Reporting Initiatives (GRI) UN } \\
\text { Global Compact or bank-specific programs for } \\
\text { compliance reasons only or, in other words, } \\
\text { considering the Libor interest rate scandal in 2012, } \\
\text { 'whether social auditing is ever going to do more } \\
\text { than gloss over the surface of a company's affairs' } \\
\text { (Confino, 2012). }\end{array}$ \\
\hline
\end{tabular}

In order to understand bullshit, we need to clarify when CSR communication and related initiatives are moving towards bullshit. To understand how to deal with CSR bullshit in banking, we apply the four-step C.R.A.P. framework from McCarthy et al. (2020). We present and discuss the four elements hereafter.

\section{The C.R.A.P. framework}

Building on the work of Frankfurt (2009), Christensen et al. (2019), Graeber (2018) and Spicer (2017), McCarthy et al. (2020) created the C.R.A.P. framework to understand and suggest ways of dealing with bullshit in workplaces. We adopt their framework and present how bullshit in CSR can be comprehended, how it can be recognised, how to act against it and how to prevent it. The next section will explain each step, discuss relevant literature and provide specific examples in a banking context to present ways how to deal with CSR bullshit.

\subsection{Comprehending CSR bullshit in banking}


There are several familiar reasons for using bullshit in CSR and corporate communications. For example, executives or managers may use bullshit-speak to give the impression of expertise or to avoid tough questions. Or, the intention behind CSR is an agenda to counter criticism or perceived threats. These agendas may be intended to serve the organisation or serve the specific departments or individuals. The main element in these CSR activities is the 'disregard of the truth, in a sense that they are not concerned with the truth, or falseness of their message but only in its efficaciousness in promoting the desired agenda' (McCarthy et al., 2020, p. 4). We argue that comprehending bullshit in banking is linked to two underlying elements: a) information or statements are presented with little or no regard for the truth and b) bullshit information or statements need to be framed to make them appealing for the relevant audience.

Regarding the presentation of information with little or no truth, managers may use at least five different communication tactics to deceive their audiences. Firstly, managers may present information that is not meaningful and therefore not understood, that is, the audience is not able to actively process the information into knowledge due to the lack of attached meaning to the data (McGongale and Vella, 2007). Secondly, through information overload created by presenting too much information so that the audience is not able to properly assess and evaluate the materials. An overload makes it difficult for the audience to uncover the underlying relevance and accuracy (Jahansoozi, 2006) particularly if cognition-related and resource-related information overload occurs (Roetzel, 2019). Thirdly, by neglecting facts audiences can only absorb what is presented to them. Information presented as a neutral and objective 'truth' can legitimate particular perspectives and interpretations and obscure the interests of the information-providers, that is, with CSR being itself a self-interested discourse, disclosing information cannot be equated with 'presenting facts' (Burchell and Cook, 2006; Humphreys and Brown, 2008). Fourth, managers may frame CSR statements to make them more appealing to customers, staff and the wider community by demonstrating the direct benefits to one particular or each of the audiences (Pérez and del Bosque, 2017). Statements and information bullshit can be achieved by confirming to audiences' interests, values, experiences or attitudes (Albarracin and Shavitt, 2018). For example, if a bank announces a vague strategy to become a more sustainable investment bank, employees that work in that institution are likely to view this positively and may even be flattered as the bullshit highlights the importance of their jobs within the organisation's purpose and value to society. A manager may use CSR statements for their organisation's and their direct personal gain (e.g. via bonus payments). For example, if an investment manager hears about how participating in social rankings drives up investment from institutional investors, the manager probably finds that narrative appealing and is more likely to act on it. Fifth, banks can make bullshit more appealing by making it more credible (Abu Zayyad et al., 2020; de Jong and van der Meer, 2017) by adding further credibility to their CSR reports. This can be achieved when independent experts and/or thought leaders announce, support or endorse strategies.

Taken together, a bullshitter can employ different tactics to persuade their audiences, in particular by providing meaningless information, information overload, false information, framing information, and by adding information credibility. The main aspect of bullshit is that it comprises a disregard for the truth and underlying agendas, thus is it important to detect bullshit, which leads to the next point: how to recognise bullshit. 


\subsection{Recognising CSR bullshit in banking}

The most important part is to recognise how CSR bullshit is disguised. Often, bullshit statements are rather abstract and formulated in a difficult and complicated way. Moreover, these statements may consist of implausible connections and gaps, lack valid sources and include buzzwords, jargon and acronyms (Cohen, 2002; Frankfurt and Wilson, 2005; Fredal, 2011; McCarthy et al., 2020).

However, at some point people inside or outside of an organisation will recognise bullshit simply because people will expect it (Berkun, 2011). Bullshit is an inherent part of every organisation as it represents a form a political behaviour or 'activities that influence, or attempt to influence, the distribution of advantages and disadvantages' (Farrell and Petersen, 1982, p. 405). In particular in a banking environment, which is characterised by increasing societal pressure, the use of bullshit can be regularly used to advance or pursue agendas to maintain legitimacy. As such, in order to recognise bullshit, it is necessary to 'develop a healthy cynicism about the possibility of bullshit' (McCarthy et al., 2020, p. 6).

There are several ways to differentiate bullshit from non-bullshit. Maybe the person announcing or presenting bullshit is a known bullshitter, thus the presenter is viewed as untrustworthy. Or statements may contradict common knowledge or specific expertise of which the audience is aware of (Pennycook, Cheyne, et al., 2015). However, audiences are often not able to recognise bullshit by confusing vagueness for profundity. In other words, 'all too often, what readers do is judge profound what they have failed to grasp' (Sperber, 2010, p. 583). The literature links this process to so-called 'conflict monitoring' failures (De Neys, 2014) where the audience lacks stimulus to further investigate the claims made and therefore will not detect the 'conflict' in the statements. In contrast, scholars found that such a 'conflict detection' may cause the audience to engage deliberatively in an analytic reasoning process (Pennycook, Fugelsang, et al., 2015) thereby taking the first step to recognise bullshit.

When discussing how to recognise bullshit, it is important to emphasise that bullshit is sometimes spread unknowingly (McCarthy et al., 2020). For instance, a senior manager informs a bank clerk about a new CSR initiative that lacks logic, but is linked to the department. The clerk may find the message appealing, has little or no time or informational constraints to check the message or is caught up in the jargon and buzzwords, thus the information is passed on to other colleagues (Spicer, 2017). The outcome of this process is that the clerk resorts to inadequate 'satisficing' (a combination of satisfy and suffice, see Fu and Gray, 2006; Sanders and Carpenter, 2003) which leads to the suboptimal decision to spread the bullshit without being aware of it.

A rather informal example to detect bullshit is the 'BlaBlaMeter' (see www.blablameter.com) which evaluates statements based on their respective substantial or non-substantial content and gives them a score between 0 and 1 (a score between 0.1 and 0.3 is considered a highquality journalistic text). The tool evaluates whether statements are dominated by a nominal style, for example, if how many verbs are used, checks the length of statements and weights certain pre-defined words and phrases to calculate a 'bullshit index' (Wurm, 2020). Although the tool focuses mainly on evaluating certain language characteristics and thus lacks capability to 'understand' the content, it clearly represents a first indicator to recognise bullshit in CSR statements. For example, the chairman statement of the NAB sustainability report 2019 (NAB, 2019) scores a 0.55, which represents rather an unsubstantiated or 'fishy' statement with the goal 'to sell something' or 'impress somebody' (BlaBlaMeter, 2020). This 
seems to be in line with other media outlets (e.g. Aliento, 2019; Bloch, 2019; Energy Matters, 2019; McArthur, 2019) who accuse NAB of greenwashing and report that a shareholder resolution has been lodged that calls for better disclosure of the sustainability targets.

The tool may also help to understand how CSR bullshit statements have changed over time. For instance, the Goldman Sachs executive summary of its environmental report in 2009 scored a 0.55, while the introductory letter of the sustainability report from 2018 (Goldman Sachs, 2018) scores 0.34, thereby both indicating that while bullshit statements have been reduced, audiences should remain critical and skeptical given CSR initiatives in banks have been criticised to promote the organisation itself rather than to advance the social good (Christensen et al., 2019). This is in line with studies (e.g. Penttilä, 2020; Ziek, 2009) showing that CSR as a tool has shifted from public relations and pure legitimacy concerns to issues of corporate governance and thus a more sophisticated language, leading to an even more concerning conclusion that although banks have learned to reduce bullshit, their underlying practices are still likely to be 'full of it' (Christensen et al., 2019; Graeber, 2018; Spicer, 2017).

It can be concluded that in order to recognise bullshit, readers of a bank's CSR report have to be vigilant and must carefully assess the written words. Although bullshit can be spread knowingly or unknowingly, audiences should be particularly skeptical when statements include circuitous, diffusing, discursive, flowery, grandiloquent, ornate or parenthetical language. Further, excess jargon and a lack of details and sources reported should raise concerns. Once we understand how to comprehend and detect bullshit, we can act against it, which is outlined in the next section.

\subsection{Acting against CSR bullshit in banking}

Acting against bullshit can occur in multiple ways. There are several ways how an audience can react to bullshit, with Hirschman (1970) being one of the first scholars to provide a framework that illustrated how staff respond to an organisation in crisis. His framework, which consists of the responses exit, voice and loyalty was extended by the response neglect (Farrell, 1983; Rusbult et al., 1988) and was subsequently used by management researcher to understand staff responses in organisations (e.g. Akhtar et al., 2016; Lee and Varon, 2020). Scholars classified these responses into constructive/active responses (voice and loyalty) and destructive/passive responses (exit and neglect) (Aravopoulou et al., 2017).

Audiences that react in destructive ways made 'the painful decision to withdraw or switch' organisations (Hirschman, 1970, p. 83). Exiting refers to 'leaving an organisation by quitting, transferring, searching for a different job, or thinking about quitting' (Rusbult et al., 1988, p. 601). In a CSR banking context, staff, customers or other audiences could be upset, frustrated or annoyed by the company's CSR bullshit, so that staying in or maintaining contact with the organisation is not an option anymore. Studies show that this response may not only lead to a loss of talent within the bank (Ladson, 2019) but also includes a reputational risk (Miklaszewska and Kil, 2017) which potentially leads to a further loss in trust and customers (Arli and Dietrich, 2017; Hurley et al., 2014).

A passive response is to neglect bullshit. Neglecting bullshit may have grave implications for employees and external audiences as they increasingly disengage with the organisation (Farrell, 1983). Employee behaviour when neglecting bullshit may include 'passively 
allowing conditions to deteriorate through reduced interest or effort, chronic lateness or absences, using company time for personal business, or increased error rate' (Rusbult et al., 1988, p. 601). In a CSR banking context, internal and external audiences will eventually distrust and lose confidence in the organisation, its communication and its leaders (McCarthy et al., 2020). In particular external audiences, such as institutional investors, may interpret an increase of bullshit as lack of governance and as a threat to their long-term investment decisions (Bushee et al., 2014; Cox et al., 2004) particularly if these are driven by ethical and sustainable investment strategies.

In contrast, voice is an constructive and active attempt to change 'an objectionable state of affairs' (Hirschman, 1970, p. 30). By voicing, audiences try to 'improve conditions through discussing problems with a supervisor or coworkers, taking action to solve problems, suggesting solutions, seeking help from an outside agency like a union, or whistle-blowing' (Rusbult et al., 1988, p. 601). In other words, audiences will confront the organisation by speaking up or asking for evidence along with the bullshit statements. However, voicing depends on what extent the audience is committed to the organisation, that is, whether the audience is embedded or interested enough in the organisation to resist or oppose the corporate bullshit. In addition, the perceived ability or authority not only to confront bullshit, but also to change it, is a necessary condition when voicing is considered (McCarthy et al., 2020). Arguably, an institutional investor will have a stronger voice than a single small-scale investor or customer and even consumer boycotts have shown weak adverse effectiveness in harming an organisation (Koku, 2012; Pruitt and Friedman, 1986).

The last option, loyalty, is also considered an active response, although it 'involves patiently waiting for the organisation to recognise and address objectionable conditions' (Lee and Varon, 2020, p. 32). In other words, audiences are 'giving public and private support to the organisation, waiting and hoping for improvement, or practicing good citizenship' (Rusbult et al., 1988, p. 601). Audiences may accept the bullshit because of loyalty to the organisation or the organisation's management, the belief that this particular bullshit benefits the organisation or just decide to go along with it (McCarthy et al., 2020). The acceptance of bullshit is particularly prevalent in the banking sector, as CSR topics are 'often ignored and regarded as perfunctory' due to the banks' nature of incentives and 'their institutionally-based cultural and ethical presuppositions' (Campbell and Slack, 2011, p. 54).

In summary, acting against bullshit occurs in either a constructive and/or destructive way. While constructive responses to address bullshit are active ways to initiate potential change, destructive responses are passive reactions that may have only a marginal impact on the organisation. However, these responses should not be viewed separately, as their interaction may indicate the extent of bullshit in an organisation. If exit and neglect responses are common, loyalty is appreciated and voicing does not exist, the organisation is probably drenched in bullshit.

\subsection{Preventing CSR bullshit in banking}

In the first three steps, the C.R.A.P. framework highlighted avenues to comprehend, recognise and act against CSR bullshit in banking. Abstracting from knowledge, we now outline three steps to prevent the creation and use of bullshit.

\subsubsection{Develop reflective thinking skills}


The first step to reduce bullshit is to develop reflective thinking skills. Studies show that individuals tend to have different ways to react to bullshit statements, a tendency Pennycook, Cheyne, et al. (2015) refer to as 'bullshit receptivity'. Their findings show that 'those more receptive to bullshit are less reflective, lower in cognitive ability' (p. 19) thus the ability to recognise and deal with bullshit is related to being a 'good reasoner'. A good reasoner has both the cognitive ability to digest relevant information and the willingness to deliberately engage in analytic reasoning processes. As such, persons with a higher analytic capability, or reflective thinking, are better suited to recognise bullshit or are more responsive to bullshit (Pennycook et al., 2014).

As a consequence, we propose that bullshit can be reduced if reflective thinking is increasingly used within an organisation. Bank employees and managers with higher reflective thinking skills should have a greater chance to evaluate the specific meaning of statements (or the lack thereof) and thus recognise the potential limitations or deceptions in these statements. As such, persons who are able to solve reasoning issues are more likely to recognise when additional scrutiny is necessary to expose bullshit and bullshit statements. As a response to increase reflective thinking skills, banks may roll out specified programs that address bullshit statements and help to detect deceptive behaviour. However, banks should differentiate between internal and external audiences, as external audiences may be more sensitive to CSR bullshit due to higher skepticism in society. Internally, banks may provide transparent answers that acknowledge and address former bullshit practices, and provide specific steps how to prevent it from occurring again. For external audiences, CSR statements and initiatives may be peer-reviewed so that harming bullshit can be exposed. The emphasis of the review can be placed on ambitious bullshit that motivates and encourage external stakeholders. More generally, regular engagement with (scientific) evidence of impacts of sustainability and CSR management should lead to more meaningful, material and factual communication (Breitbarth and Herold, 2018).

\subsubsection{Adjust the incentive structure}

The second step to reduce bullshit is to adjust the underlying incentive structures for bankers. As Stiglitz (2010, p. 6) observes, 'bankers acted greedily because they had incentives and opportunities to do so, and that is what has to be changed'. Studies show that banks have a temptation to engage in moral hazard, as their too big to fail status and the associated bailout guarantees increases the risks appetite of banks (Cornett et al., 2016; Mattana and Rossi, 2016; Zhang et al., 2016). In particular, risk-taking incentives as part of compensation arrangements in the banking sector have been identified as a key contributing factor, for example, to the GFC (Esteban-Sanchez et al., 2017; Murray et al., 2017). The common use of the Anglo-Saxon shareholder model in banking - aligning incentive rewards with share price performance - can be regarded as the moral and philosophical basis for such compensation practices (Mattana and Rossi, 2016; Quinn and Jones, 1995). As a consequence, we propose that bullshit can be reduced when incentive structures are more aligned with social responsibility goals. Although scholars found that the GFC has served as a 'wakeup call' (Cornett et al., 2016) for banks to engage more in social responsible activities, they recommend to further incorporate CSR in regulatory frameworks or establish stronger CSRrelated policies. 
As a response to integrate CSR more strategically into incentive structures, banks may strengthen corporate governance mechanisms. The voluntary nature of CSR often lacks mechanisms to assess whether or how banks implement CSR. However, monitoring mechanisms or independent assurance statements prepared by authorised third parties may strengthen CSR activities and mitigate the related motivation of bankers to make high-risk investments. In particular, corporate governance mechanisms should be linked to effective accountability and more transparent incentive structures, so that CSR bullshit that would deal with the aftermath does not occur in the first place.

\subsubsection{Simplify the language and demonstrate impact}

Bullshit is inherently linked to jargon, acronyms and abbreviations (Frankfurt, 2009; Fredal, 2011; Spicer, 2017). In fact, jargon is a key driver used to legitimise bullshit, as it pretends alleged expertise in statements and thus makes the message objective and professional (McCarthy et al., 2020). The banking sector is particularly attracted to jargon as financial markets thrive on new ways to raise money and thus discover new words (such as 'securitisation') or have to react to regulation by inventing new products with bullshit names (such as 'CDOs' or 'collateralised debt obligations') (Paterson and Mallesons, 1997).

As a consequence, we propose that bullshit can be reduced if the use of jargon, acronyms and abbreviations is significantly reduced within an organisation and external audiences. For example, although acronyms can help to save time, they may alienate external audiences. Moreover, words such 'collateralised debt obligations' may be used inside banking audiences, but for external audiences it may be intimidating.

As a response to reduce bullshit acronyms and jargon in statements, banks may run their statements through a readability level test so that the statement can be understood by an average $4^{\text {th }}$ grade student (see Apple press release strategy, Craig, 2016). This may include not only the removal of any hint of acronyms and jargon, but also an approval chain up to the CEO. Banks may also introduce hands-on briefings to relevant external audiences not only to shape stories, but also to 'course-correct' in case the audiences' perception's deviate from the key message.

\section{Conclusion}

Our paper builds upon the grown relevance of corporate and management communication and - at the same time - its increasing undermining by indifference to truth and meaning. It responds to emerging research into manifestations of bullshit and seeks to contribute to this stream by deconstructing and evaluating its occurrences in the financial sector. More specifically, this study makes three contributions: First, we expand existing research on bullshit by linking it to banking, thereby providing a much narrower focus to better understand the implications in the financial industry. Second, we broaden the CSR literature by constructing a typology that describes the bullshit phenomena, thereby expanding literature in the context of CSR communication tools. Third, we apply the C.R.A.P. framework to discuss critical bullshit concepts, challenges and opportunities, thereby presenting a clear and comprehensive structure that allows academics and managers to comprehend, recognise, act against and prevent bullshit in banking. 
However, from a practical perspective, reducing management-bullshit will require a collective effort and it goes beyond comprehending and recognising bullshit. The banking industry offers structural differences to other industries; has its own language and a unique set of traditions that, arguably, are threatened by the increasing use of bullshit. Our suggestions may help to eliminate some of the rhetorical issues. It remains to further investigation to identify if bullshitting is the The Good, The Bad or The Ugly, for example, if bullshitting is related to certain management styles and corporate performance; is an expression of increasing riskavoidance and legal compliance; or if it is only 'bad' use of language and communication. However, we remain concerned that there are deeper rooted problems at play, indicating that while the rhetoric can be fixed, more research must occur to critically question and assess the underlying CSR practices in banks and how they can actually help drive the social good (Szablewska and Kubacki, 2019).

Especially in the context of a sensible and stakeholder-oriented topic such as CSR, we should continue to observe if, for example, tighter governmental regulation of the sector and stricter requirements on non-financial reporting will have an influence on narratives and terminology used. Moreover, to better understand the genuineness of CSR statements, future research may evaluate corporate statements using the 'BlaBlaMeter' to assess similarities and differences between industries or companies. Still, while this paper puts a spotlight on written and spoken language, the use of still imagery in corporate communications and non-financial reporting (Breitbarth et al., 2010) should not be neglected as 'many kinds of problems ... be resolved, dissolved, dispersed or transformed depending on how pictures and design are handled' (Squiecs, 1989, p. 208). Furthermore, the potential for factual hollowness in corporate social media communication via stories, videos and other forms of moving pictures needs to be added to the bullshit research agenda. Cheney et al. (2007) emphasise the significant influence that language and imagery have on the creation of understanding, meaning and the 'reality' of a contested idea like social responsibility. This is particularly concerning given the discussed scarcity of cognitive capacity in human beings (Datta and Mullainathan, 2014) which, in turn, may be more easily exploited when using visual cues in favour of words.

Clearly, some elements of current conceptualisations, definitions and accepted practices of CSR are playing into the cards of those indulging in indifference to an ethos of truth and caring. Indeed, management researchers create and contribute extensively to bullshit (Eubanks and Schaeffer, 2008; Fredal, 2011). Almost 50 years ago, Votaw (1972) described social responsibility as a 'brilliant' term because 'it means something, but not always the same thing, to everybody' (p. 25). Even the term CSR itself may also be interpreted as bullshit by some managers and researchers alike, as 'CSR', 'sustainability', 'citizenship' or 'shared values' are used interchangeably in corporate and academic worlds. Yet, we believe both meaningful social responsibility and caring management communication are worth to aspire and uphold - because both are invaluable for our challenging (business) world. 


\section{References}

Abu Zayyad, H.M., Obeidat, Z.M., Alshurideh, M.T., Abuhashesh, M., Maqableh, M. and Masa'deh, R. (2020), "Corporate social responsibility and patronage intentions: The mediating effect of brand credibility", Journal of Marketing Communications, pp. 124.

Akhtar, M.N., Bal, M. and Long, L. (2016), "Exit, voice, loyalty, and neglect reactions to frequency of change, and impact of change", Employee Relations, Vol. 38 No. 4, pp. 536-562.

Albarracin, D. and Shavitt, S. (2018), "Attitudes and attitude change", Annual review of psychology, Vol. 69, pp. 299-327.

Alberici, E. (2018), "Royal commission casts a shadow over banks' corporate good deeds". $A B C$. Retrieved from https://www.abc.net.au/news/2018-11-02/bank-corporate-socialresponsibility-royal-commission/10456964

Aliento, W. (2019), "NAB's messaging on coal and sustainability". The Fifth State. Retrieved from https://www.thefifthestate.com.au/business/finance/nabs-messaging-on-coal-andsustainability/

Aravopoulou, E., Mitsakis, F.V. and Malone, C. (2017), "A critical review of the Exit-VoiceLoyalty-Neglect literature: limitations, key challenges and directions for future research", The International Journal of Management, Vol. 6 No. 3, pp. 1-10.

Arli, D. and Dietrich, T. (2017), "Can social media campaigns backfire? Exploring consumers' attitudes and word-of-mouth toward four social media campaigns and its implications on consumer-campaign identification", Journal of Promotion Management, Vol. 23 No. 6, pp. 834-850.

Arli, D. and Tjiptono, F. (2014), "Does corporate social responsibility matter to consumers in Indonesia?", Social Responsibility Journal, Vol. 10 No. 3, pp. 537-549.

Arli, D., van Esch, P., Northey, G., Lee, M.S. and Dimitriu, R. (2019), "Hypocrisy, skepticism, and reputation: the mediating role of corporate social responsibility", Marketing Intelligence \& Planning, Vol. 37 No. 6, pp. 706-720.

Arli, D.I. (2010). "Drivers and Measures of Corporate Social Responsibility: Initiatives in Community Involvement". Paper presented at the Australia and New Zealand Academy of Management (ANZAM) Conference Proceedings.

Arli, D.I. and Lasmono, H.K. (2010), "Consumers' perception of corporate social responsibility in a developing country", International Journal of Consumer Studies, Vol. 34 No. 1, pp. 46-51.

Australian Prudential Regulation Authority (2018), "Prudential Inquiry into the Commonwealth Bank of Australia - Final Report". Retrieved from Sydney, Australia: https://www.apra.gov.au/sites/default/files/CBA-Prudential-Inquiry_FinalReport_30042018.pdf

Ball, J. (2017), Post-truth: How bullshit conquered the world, Biteback Publishing, London, UK.

Barth, R. and Wolff, F. (2009), Corporate social responsibility in Europe: Rhetoric and realities, Edward Elgar, Cheltenham, UK.

Battersby, L. (2016), "NAB brand refresh recognises consumer uncertainty". Sydney Morning Herald. Retrieved from https://www.smh.com.au/business/companies/nab-brandrefresh-recognises-consumer-uncertainty-20160708-gq1 cat.html

Bennett, R. and Kottasz, R. (2012), "Public attitudes towards the UK banking industry following the global financial crisis", International Journal of Bank Marketing, Vol. 30 No. 2, pp. 128-147.

Berkun, S. (2011), Mindfire: Big ideas for curious minds, BookBaby, Pennsauken, NJ.

Berthon, P.R. and Pitt, L.F. (2018), "Brands, truthiness and post-fact: managing brands in a post-rational world", Journal of Macromarketing, Vol. 38 No. 2, pp. 218-227. 
BlaBlaMeter. (2020). BlaBlaMeter - how much bullshit hides in your text? Retrieved from http://www.blablameter.com/index.php

Bloch, M. (2019), "NAB Coal, Renewable Energy Commitments Criticised". Solarquotes Blog. Retrieved from https://www.solarquotes.com.au/blog/nab-renewables-coal$\underline{\mathrm{mb} 1294 /}$

Branco, M.C. and Rodrigues, L.L. (2006), "Communication of corporate social responsibility by Portuguese banks: A legitimacy theory perspective", Corporate Communications, Vol. 11 No. 3, pp. 232-248. doi:10.1108/13563280610680821

Breitbarth, T. (2011), The business case for corporate social responsibility: Evolution, construction and manifestation in Europe, AVM, Munich, Germany.

Breitbarth, T., Harris, P. and Insch, A. (2010), "Pictures at an exhibition revisited: reflections on a typology of images used in the construction of corporate social responsibility and sustainability in non-financial corporate reporting", Journal of Public Affairs, Vol. 10 No. 4, pp. 238-257.

Breitbarth, T. and Herold, D.M. (2018), "Closing the academia-practice gap in corporate sustainability management research: Challenges and bridges", Journal of Environmental Sustainability, Vol. 6 No. 1, p. 4.

Breitbarth, T., Hovemann, G. and Walzel, S. (2011), "Scoring strategy goals: Measuring corporate social responsibility in professional European football", Thunderbird International Business Review, Vol. 53 No. 6, pp. 721-737. doi:10.1002/tie.20448

Breitbarth, T., Schaltegger, S. and Mahon, J. (2018), "The business case for sustainability in retrospect: A Scandinavian institutionalism perspective on the role of expert conferences in shaping the emerging "CSR and corporate sustainability space"", Journal of Public Affairs, Vol. 18 No. 3, p. e1855.

Brennan, T. (1987), "Classification: An overview of selected methodological issues", in Gottfredson, M. and Tonry, M. (Eds.), Prediction and classification, University of Chicago Press, Chicago, pp. 201-248.

Brønn, P.S. and Vrioni, A.B. (2001), "Corporate social responsibility and cause-related marketing: an overview", International Journal of Advertising, Vol. 20 No. 2, pp. 207222.

Burchell, J. and Cook, J. (2006), "It's good to talk? Examining attitudes towards corporate social responsibility dialogue and engagement processes", Business Ethics: A European Review, Vol. 15 No. 2, pp. 154-170.

Bushee, B.J., Carter, M.E. and Gerakos, J. (2014), "Institutional investor preferences for corporate governance mechanisms", Journal of Management Accounting Research, Vol. 26 No. 2, pp. 123-149.

Campbell, D. and Slack, R. (2011), "Environmental disclosure and environmental risk: Sceptical attitudes of UK sell-side bank analysts", The British Accounting Review, Vol. 43 No. 1, pp. 54-64.

Castelo, B.M. (2013), "Banks and CSR", in Idowu, S.O., Capaldi, N., Zu, L. and Gupta, A.D. (Eds.), Encyclopedia of Corporate Social Responsibility, Springer, Berlin, Heidelberg, pp. 141-148.

Chambers, C. and Day, R. (2009), "The banking sector and CSR: An unholy alliance?", Financial Regulation International, Vol. 12 No. 9, pp. 1-7.

Cheney, G., May, S.K. and Roper, J. (2007), "Overview", in May, S.K., Cheney, G. and Roper, J. (Eds.), The debate over corporate social responsibility, Oxford University Press, New York, pp. 3-12.

Chomvilailuk, R. and Butcher, K. (2013), "The effect of CSR knowledge on customer liking, across cultures", International Journal of Bank Marketing, Vol. 31 No. 2, pp. 98-114.

Christensen, L.T., Kärreman, D. and Rasche, A. (2019), "Bullshit and Organization Studies", Organization Studies, Vol. 40 No. 10, pp. 1587-1600. 
CNBC (2018), "Wells Fargo to pay \$575 million in settlement with US states. ". Retrieved from https://www.cnbc.com/2018/12/28/wells-fargo-to-pay-at-least-500-million-insettlement-with-us-states.html

Cohen, G.A. (2002), "Deeper into bullshit", in Buss, S. and Overton, L. (Eds.), Contours of agency: Essays on themes from Harry Frankfurt, MIT Press, Boston, MA, pp. 321339.

Cohen, G.A. (2012), "Complete Bullshit", in Otuska, M. (Ed.), Finding Oneself in the Other, Princeton University Press, Princeton, NJ, pp. 94-114.

Collins, M. (2015), "The Big Bank Bailout". Forbes. Retrieved from https://www.forbes.com/sites/mikecollins/2015/07/14/the-big-bankbailout/\#164360fb2d83

Compas, B.E., Hinden, B.R. and Gerhardt, C.A. (1995), "Adolescent development: Pathways and processes of risk and resilience", Annual review of psychology, Vol. 46 No. 1, pp. 265-293.

Condosta, L. (2012), "How banks are supporting local economies facing the current financial crisis: An Italian perspective", The International Journal of Bank Marketing, Vol. 30 No. 6, pp. 485-502.

Confino, J. (2012), "Has Barclays brought corporate responsibility reporting into disrepute? ". Guardian. Retrieved from https://www.theguardian.com/sustainablebusiness/barclays-corporate-responsibility-reporting-disrepute

Cooke, N.A. (2017), "Posttruth, truthiness, and alternative facts: Information behavior and critical information consumption for a new age", The Library Quarterly, Vol. 87 No. 3, pp. 211-221.

Coombs, W.T. and Holladay, S.J. (2013), "The pseudo-panopticon: The illusion created by CSR-related transparency and the internet", Corporate Communications: An International Journal, Vol. 18 No. 2, pp. 212-227.

Cornett, M.M., Erhemjamts, O. and Tehranian, H. (2016), "Greed or good deeds: An examination of the relation between corporate social responsibility and the financial performance of US commercial banks around the financial crisis", Journal of Banking \& Finance, Vol. 70, pp. 137-159.

Cox, P., Brammer, S. and Millington, A. (2004), "An empirical examination of institutional investor preferences for corporate social performance", Journal of Business Ethics, Vol. 52 No. 1, pp. 27-43.

Craig, C. (2016), "What I Learned From 10 Years of Doing PR for Apple". Harvard Business Review.

Datta, S. and Mullainathan, S. (2014), "Behavioral design: a new approach to development policy", Review of Income and Wealth, Vol. 60 No. 1, pp. 7-35.

de Jong, M.D. and van der Meer, M. (2017), "How does it fit? Exploring the congruence between organizations and their corporate social responsibility (CSR) activities", Journal of Business Ethics, Vol. 143 No. 1, pp. 71-83.

De Neys, W. (2014), "Conflict detection, dual processes, and logical intuitions: Some clarifications", Thinking \& Reasoning, Vol. 20 No. 2, pp. 169-187.

Debeljak, J., Krkač, K. and Banks, I.B. (2011), "Acquiring CSR practices: from deception to authenticity", Social Responsibility Journal, Vol. 7 No. 1, pp. 5-22.

Deloitte (2018), "Deloitte Trust Index - Banking 2018 - The way forward to rebuild reputation and trust". Retrieved from Melbourne, Australia:

https://www2.deloitte.com/au/en/pages/financial-services/articles/deloitte-trust-indexbanking-survey.html

Dobscha, S. (1998), "The lived experience of consumer rebellion against marketing", in Alba, J.W. and Hutchinson, J.W. (Eds.), North American Advances in Consumer Research Association for Consumer Research, Provo, UT, pp. 91-97. 
Donia, M.B. and Sirsly, C.-A.T. (2016), "Determinants and consequences of employee attributions of corporate social responsibility as substantive or symbolic", European Management Journal, Vol. 34 No. 3, pp. 232-242.

Edelman Trust Barometer (2020), "2020 Edelmann Trust Barometer". Retrieved from https://edl.mn/2NOwltm

Energy Matters (2019), "NAB's renewable energy commitments under scrutiny". Energy Matters. Retrieved from https://www.energymatters.com.au/renewable-news/nabsrenewable-energy-commitments-under-scrutiny/

Esteban-Sanchez, P., de la Cuesta-Gonzalez, M. and Paredes-Gazquez, J.D. (2017), "Corporate social performance and its relation with corporate financial performance: International evidence in the banking industry", Journal of Cleaner Production, Vol. 162, pp. 1102-1110.

Eubanks, P. and Schaeffer, J.D. (2008), "A kind word for bullshit: The problem of academic writing", College Composition and Communication, Vol. 59 No. 3, pp. 372-388.

European Commisson (2013), "How Companies influence our society: Citizens' view". Retrieved from Brussels: https://ec.europa.eu/commfrontoffice/publicopinion/flash/fl 363 sum en.pdf.

Farrell, D. (1983), "Exit, voice, loyalty, and neglect as responses to job dissatisfaction: A multidimensional scaling study", Academy of Management Journal, Vol. 26 No. 4, pp. 596-607.

Farrell, D. and Petersen, J.C. (1982), "Patterns of political behavior in organization", Academy of Management Review, Vol. 7 No. 3, pp. 403-412.

Fatma, M. and Rahman, Z. (2016), "The CSR's influence on customer responses in Indian banking sector", Journal of Retailing and Consumer Services, Vol. 29, pp. 49-57.

Fatma, M., Rahman, Z. and Khan, I. (2015), "Building company reputation and brand equity through CSR: the mediating role of trust", International Journal of Bank Marketing, Vol. 33 No. 6, pp. 840-856.

Fisher, L.E. (2009), "Target marketing of subprime loans: Racialized consumer fraud \& reverse redlining", Journal of Law and Policy, Vol. 18 No. 1/3, pp. 121-155.

Fitzgerald, P. (2009), "Fund Manager Wants \$12.3M From Lehman". The Wall Street Journal. Retrieved from https://blogs.wsj.com/bankruptcy/2009/09/11/fund-managerwants-123m-from-lehman/

Flaxman, S., Goel, S. and Rao, J.M. (2016), "Filter bubbles, echo chambers, and online news consumption", Public Opinion Quarterly, Vol. 80 No. S1, pp. 298-320.

Frankfurt, H. (2009), "On Truth, Lies, and Bullshit", in Martin, C. (Ed.), The Philosophy of Deception, Oxford University Press, Oxford, UK, pp. 37-48.

Frankfurt, H.G. and Wilson, G. (2005), On bullshit, Princeton University Press, Princeton, NJ.

Fredal, J. (2011), "Rhetoric and bullshit", College English, Vol. 73 No. 3, pp. 243-259.

Fu, W.-T. and Gray, W.D. (2006), "Suboptimal tradeoffs in information seeking", Cognitive Psychology, Vol. 52 No. 3, pp. 195-242.

Gandy, B. (2019), "'21st century scandals: towards a risk approach to financial reporting scandals': a practitioner view", Accounting and Business Research, Vol. 49 No. 5, pp. 536-539.

Goldman Sachs (2018), "Sustainability Report". Retrieved from http://www.goldmansachs.com/citizenship/sustainability-reporting/report.pdf

Graeber, D. (2018), Bullshit jobs, Simon \& Schuster, New York.

Hellmann, T.F., Murdock, K.C. and Stiglitz, J.E. (2000), "Liberalization, moral hazard in banking, and prudential regulation: Are capital requirements enough?", American economic review, Vol. 90 No. 1, pp. 147-165. 
Herold, D.M. and Lee, K.-H. (2017), "The Influence of the Sustainability Logic on Carbon Disclosure in the Global Logistics Industry: The Case of DHL, FDX and UPS", Sustainability, Vol. 9 No. 4, p. 601. doi:10.3390/su9040601

Hirschman, A.O. (1970), Exit, voice, and loyalty: Responses to decline in firms, organizations, and states, Harvard University Press, Boston, MA.

Hooton, A. (2018), "Why good people do bad things". The Sydney Morning Herald. Retrieved from https://www.smh.com.au/money/banking/why-good-people-do-bad-things20180716-p4zrq5.html

Hopkin, J. and Rosamond, B. (2018), "Post-truth politics, bullshit and bad ideas:'Deficit Fetishism'in the UK", New Political Economy, Vol. 23 No. 6, pp. 641-655.

Hudson, A. (2014), Great debates in equity and trusts, Plagrave Macmillan, London, UK.

Humphreys, M. and Brown, A.D. (2008), "An analysis of corporate social responsibility at credit line: A narrative approach", Journal of Business Ethics, Vol. 80 No. 3, pp. $403-$ 418.

Hurley, R., Gong, X. and Waqar, A. (2014), "Understanding the loss of trust in large banks", International Journal of Bank Marketing, Vol. 32 No. 5, pp. 348-366.

Ioannou, S., Wójcik, D. and Dymski, G. (2019), "Too-Big-To-Fail: Why Megabanks Have Not Become Smaller Since the Global Financial Crisis?", Review of Political Economy, Vol. 31 No. 3, pp. 356-381.

Jahansoozi, J. (2006), "Relationships, transparency and evaluation: The implications for public relations", in L'Etang, J. and Pieczka, M. (Eds.), Public relations: Critical debates and contemporary practice, Lawrence Erlbaum Associates, Mahwah, NJ, pp. 61-91.

Jizi, M.I., Salama, A., Dixon, R. and Stratling, R. (2014), "Corporate governance and corporate social responsibility disclosure: Evidence from the US banking sector", Journal of Business Ethics, Vol. 125 No. 4, pp. 601-615.

Johnson, S. and Kwak, J. (2010), 13 bankers: The Wall Street takeover and the next financial meltdown, Panethon Books, New York.

Keyes, R. (2004), The post-truth era: Dishonesty and deception in contemporary life, St. Martin's Press, New York.

Khan, I., Rahman, Z. and Fatma, M. (2016), "The role of customer brand engagement and brand experience in online banking", International Journal of Bank Marketing, Vol. 34 No. 7, pp. 1025-1041.

Kim, Y.J. and Lee, W.-N. (2009), "Overcoming consumer skepticism in cause-related marketing: The effects of corporate social responsibility and donation size claim objectivity", Journal of Promotion Management, Vol. 15 No. 4, pp. 465-483.

Koku, P.S. (2012), "On the effectiveness of consumer boycotts organized through the internet: the market model", Journal of Services Marketing, Vol. 26 No. 1, pp. 20-26.

Ladson, D.A. (2019). Strategies for Increasing Employee Morale and Mitigating Turnover in the Banking Industry. (Doctor of Business Administration (D.B.A.)), Walden University, Minneapolis, MN.

Lanchester, J. (2014), "John Lanchester: the worst jargon in economics and banking ". Guardian. Retrieved from https://www.theguardian.com/business/2014/sep/23/johnlanchester-the-worst-jargon-in-economics-and-banking

Lanin, S. (2018), "Banking royal commission: Banks and AMP face criminal charges and \$1b bill in fee-for-no-service scandal". Australian Broadcasting Corporation. Retrieved from https://www.abc.net.au/news/2018-08-17/apra-under-fire-for-failing-to-policesuperannuation-industry/10129612

Lee, J. and Varon, A.L. (2020), "Employee exit, voice, loyalty, and neglect in response to dissatisfying organizational situations: It depends on supervisory relationship quality", International Journal of Business Communication, Vol. 57 No. 1, pp. 30-51. 
Lee, K.-H., Herold, D.M. and Yu, A.-L. (2016), "Small and Medium Enterprises and Corporate Social Responsibility Practice: A Swedish Perspective", Corporate Social Responsibility and Environmental Management, Vol. 23 No. 2, pp. 88-99. doi:10.1002/csr.1366

Lee, L.W., Hannah, D. and McCarthy, I.P. (2019), "Do your employees think your slogan is "fake news?" A framework for understanding the impact of fake company slogans on employees", Journal of Product \& Brand Management.

List, J.A. and Momeni, F. (2017), "When corporate social responsibility backfires: Theory and evidence from a natural field experiment" (0898-2937). Retrieved from Cambridge, MA: http://www.nber.org/papers/w24169

Lock, I. and Seele, P. (2015), "Analyzing sector-specific CSR reporting: Social and environmental disclosure to investors in the chemicals and banking and insurance industry", Corporate Social Responsibility and Environmental Management, Vol. 22 No. 2, pp. 113-128.

Luyendijk, J. (2016), "Big banks still have a problem with ethics and morality ". Guardian. Retrieved from https://www.theguardian.com/sustainable-business/2016/jan/18/bigbanks-problem-ethics-morality-davos

MacDonald, L.G. and Robinson, P. (2010), A colossal failure of common sense: The inside story of the collapse of Lehman brothers, Crown Business Press, New York.

MacDonald, S.B. (2017), Separating fools from their money: A history of American financial scandals, Routledge, New York, US.

Maley, K. (2018), "Banking royal commission: Which bank boss made the best witness? ". Financial Review. Retrieved from https://www.afr.com/companies/financialservices/banking-royal-commission-henrys-haughty-didnt-play-well-elliotts-pay-cutdid-20181129-h18iok

Mattana, P. and Rossi, S.P. (2016), "Moral-hazard conduct in the European banks during the first wave of the Global Financial Crisis", in S., R. and R., M. (Eds.), Financial Crisis, Bank Behaviour and Credit Crunch, Springer, Cham, pp. 39-52.

McArthur, E. (2019), "NAB accused of greenwashing". Financial Standard. Retrieved from https://www.financialstandard.com.au/news/nab-accused-of-greenwashing-149452511

McCarthy, I.P., Hannah, D., Pitt, L.F. and McCarthy, J.M. (2020), "Confronting indifference toward truth: Dealing with workplace bullshit", Business Horizons.

McDonald, L. (2014), "Corporate Social Responsibility (CSR) in banking: what we know, what we don't know and what we should know", in Harrison, T. and Estelami, H. (Eds.), Companion to Financial Services Marketing, Routledge, London, pp. 485-505.

McDonald, L.M. and Lai, C.H. (2011), "Impact of corporate social responsibility initiatives on Taiwanese banking customers", International Journal of Bank Marketing, Vol. 29 No. 1, pp. 50-63.

McDonald, L.M. and Rundle-Thiele, S. (2008), "Corporate social responsibility and bank customer satisfaction", International Journal of Bank Marketing, Vol. 26 No. 3, pp. 170-182.

McGongale, J. and Vella, C. (2007), "I spy your company secrets". Security Management, February 2007, 64-70.

McGrath, M. (2016), "Wells Fargo Fined \$185 Million For Opening Accounts Without Customers' Knowledge". Forbes. Retrieved from https://www.forbes.com/sites/maggiemcgrath/2016/09/08/wells-fargo-fined-185million-for-opening-accounts-without-customers-knowledge/\#9c7b4f251fca

Mihailidis, P. and Viotty, S. (2017), "Spreadable spectacle in digital culture: Civic expression, fake news, and the role of media literacies in "post-fact" society", American Behavioral Scientist, Vol. 61 No. 4, pp. 441-454. 
Miklaszewska, E. and Kil, K. (2017), "Reputational risk in banking: Important to whom?", in Chesini, G., Giaretta, E. and Paltrinieri, A. (Eds.), The Business of Banking, Springer, Cham, pp. 109-129.

Mogaji, E., Soetan, T.O. and Kieu, T.A. (2020), "The implications of artificial intelligence on the digital marketing of financial services to vulnerable customers", Australasian Marketing Journal (AMJ).

Moon, M.J. (2002), "The evolution of e-government among municipalities: rhetoric or reality?", Public Administration Review, Vol. 62 No. 4, pp. 424-433.

Munro, V., Arli, D. and Rundle-Thiele, S. (2016). "CSR Strategy at a Crossroads: An example of a Multinational Corporation in a Developing and Developed Society". Paper presented at the Proceedings of the International Association for Business and Society.

Munro, V., Arli, D. and Rundle-Thiele, S. (2018), "CSR engagement and values in a preemerging and emerging country context", International Journal of Emerging Markets, Vol. 13 No. 5, pp. 1251-1272.

Murray, N., Manrai, A.K. and Manrai, L.A. (2017), "The financial services industry and society", Journal of Economics, Finance and Administrative Science, Vol. 22 No. 43, pp. 168-190.

NAB (2019), "Sustainability Report". Retrieved from Brisbane, AU: https://www.nab.com.au/content/dam/nabrwd/documents/reports/corporate/2019sustainability-report-pdf.pdf

Norberg, P. (2018), "Bankers bashing back: Amoral CSR justifications", Journal of Business Ethics, Vol. 147 No. 2, pp. 401-418.

Paterson, I. and Mallesons, S.J. (1997), "Banking and Finance-Demystifying the Jargon", Australian Law Librarian, Vol. 5 No. 1, pp. 64-69.

Pennycook, G., Cheyne, J.A., Barr, N., Koehler, D.J. and Fugelsang, J.A. (2014), "The role of analytic thinking in moral judgements and values", Thinking \& Reasoning, Vol. 20 No. 2, pp. 188-214.

Pennycook, G., Cheyne, J.A., Barr, N., Koehler, D.J. and Fugelsang, J.A. (2015), "On the reception and detection of pseudo-profound bullshit", Judgment and Decision Making, Vol. 10 No. 6, pp. 549-563.

Pennycook, G., Fugelsang, J.A. and Koehler, D.J. (2015), "Everyday consequences of analytic thinking", Current Directions in Psychological Science, Vol. 24 No. 6, pp. 425-432.

Penttilä, V. (2020), "Aspirational talk in strategy texts: A longitudinal case study of strategic episodes in corporate social responsibility communication", Business \& Society, Vol. 59 No. 1, pp. 67-97.

Pérez, A. and Del Bosque, I.R. (2012), "The role of CSR in the corporate identity of banking service providers", Journal of Business Ethics, Vol. 108 No. 2, pp. 145-166.

Pérez, A. and del Bosque, I.R. (2017), "Personal traits and customer responses to CSR perceptions in the banking sector", International Journal of Bank Marketing, Vol. 35 No. 1, pp. 128-146.

Petrocelli, J.V. (2018), "Antecedents of bullshitting", Journal of Experimental Social Psychology, Vol. 76, pp. 249-258.

Poolthong, Y. and Mandhachitara, R. (2009), "Customer expectations of CSR, perceived service quality and brand effect in Thai retail banking", International Journal of Bank Marketing, Vol. 27 No. 6, pp. 408-427.

Pope, S. and Wæraas, A. (2016), "CSR-washing is rare: A conceptual framework, literature review, and critique", Journal of Business Ethics, Vol. 137 No. 1, pp. 173-193.

Prasad, A. and Holzinger, I. (2013), "Seeing through smoke and mirrors: A critical analysis of marketing CSR", Journal of Business Research, Vol. 66 No. 10, pp. 1915-1921. 
Pruitt, S.W. and Friedman, M. (1986), "Determining the effectiveness of consumer boycotts: A stock price analysis of their impact on corporate targets", Journal of Consumer Policy, Vol. 9 No. 4, pp. 375-387.

Quinn, D.P. and Jones, T.M. (1995), "An agent morality view of business policy", Academy of Management Review, Vol. 20 No. 1, pp. 22-42.

Rasche, A. (2018), "Why Corporate Sustainability is Bullshit (And Why This is a Good Thing)". BOS - The Business of Society. Retrieved from http://www.boscbscsr.dk/2018/11/29/why-corporate-sustainability-is-bullshit/

Rim, H. and Kim, S. (2016), "Dimensions of corporate social responsibility (CSR) skepticism and their impacts on public evaluations toward CSR", Journal of Public Relations Research, Vol. 28 No. 5-6, pp. 248-267.

Roetzel, P.G. (2019), "Information overload in the information age: a review of the literature from business administration, business psychology, and related disciplines with a bibliometric approach and framework development", Business Research, Vol. 12 No. 2, pp. 479-522.

Rundle-Thiele, S., Leo, C., Scharf, E.R., Fernandes, J. and Kormann, B.D. (2012), "Corporate social responsibility to build strong Brazilian bank brand", International Journal of Bank Marketing, Vol. 30 No. 6, pp. 430-451.

Rusbult, C.E., Farrell, D., Rogers, G. and Mainous III, A.G. (1988), "Impact of exchange variables on exit, voice, loyalty, and neglect: An integrative model of responses to declining job satisfaction", Academy of Management Journal, Vol. 31 No. 3, pp. 599627.

Sanders, W.G. and Carpenter, M.A. (2003), "Strategic satisficing? A behavioral-agency theory perspective on stock repurchase program announcements", Academy of Management Journal, Vol. 46 No. 2, pp. 160-178.

Scrizzi, M. (2007), "Punk marketing", Journal of Consumer Marketing, Vol. 24 No. 7, pp. 445-446.

Seele, P. and Lock, I. (2015), "Instrumental and/or deliberative? A typology of CSR communication tools", Journal of Business Ethics, Vol. 131 No. 2, pp. 401-414.

Shim, K. and Yang, S.-U. (2016), "The effect of bad reputation: The occurrence of crisis, corporate social responsibility, and perceptions of hypocrisy and attitudes toward a company", Public Relations Review, Vol. 42 No. 1, pp. 68-78.

Skarmeas, D. and Leonidou, C.N. (2013), "When consumers doubt, watch out! The role of CSR skepticism", Journal of Business Research, Vol. 66 No. 10, pp. 1831-1838.

Slack, K. (2012), "Mission impossible?: Adopting a CSR-based business model for extractive industries in developing countries", Resources Policy, Vol. 37 No. 2, pp. 179-184.

Sperber, D. (2010), "The guru effect", Review of Philosophy and Psychology, Vol. 1 No. 4, pp. 583-592.

Spicer, A. (2017), Business bullshit, Routledge, London, UK.

Squiecs, C. (1989), "The corporate year in pictures", in Bolton, R. (Ed.), The Contest of Meaning, MIT Press, Cambridge, MA, pp. 207-218.

Stiglitz, J.E. (2010), Freefall: America, free markets, and the sinking of the world economy, WW Norton \& Company, New York.

Szablewska, N. and Kubacki, K. (2019), "A human rights-based approach to the social good in social marketing", Journal of Business Ethics, Vol. 155 No. 3, pp. 871-888.

Toms, S. (2019), "Financial scandals: a historical overview", Accounting and Business Research, Vol. 49 No. 5, pp. 477-499.

Treasury Committee (2008), "Banking Crisis: reforming corporate governance and pay in the City", Ninth Report of the Session, Vol. 9.

Votaw, D. (1972), "Genius becomes rare: A comment on the doctrine of social responsibility Pt. I", California Management Review, Vol. 15 No. 2, pp. 25-31. 
Weber, O., Diaz, M. and Schwegler, R. (2014), "Corporate social responsibility of the financial sector-strengths, weaknesses and the impact on sustainable development", Sustainable Development, Vol. 22 No. 5, pp. 321-335.

Whittle, A. and Mueller, F. (2012), "Bankers in the dock: Moral storytelling in action", Human Relations, Vol. 65 No. 1, pp. 111-139.

Wiek, A. and Weber, O. (2014), "Sustainability challenges and the ambivalent role of the financial sector", Journal of Sustainable Finance \& Investment, Vol. 4 No. 1, pp. 9-20.

Wurm, B. (2020). Häufige Fragen zum BlaBalMeter. Retrieved from http://www.blablameter.de/fragen_und_antworten.html

Xu, Y., Shieh, C.-H., van Esch, P. and Ling, I.-L. (2020), "AI customer service: Task complexity, problem-solving ability, and usage intention", Australasian Marketing Journal (AMJ).

Zhang, D., Cai, J., Dickinson, D.G. and Kutan, A.M. (2016), "Non-performing loans, moral hazard and regulation of the Chinese commercial banking system", Journal of Banking \& Finance, Vol. 63, pp. 48-60.

Ziek, P. (2009), "Making sense of CSR communication", Corporate Social Responsibility and Environmental Management, Vol. 16 No. 3, pp. 137-145. 